\title{
Improving PEM fuel cell performance using in-line triangular baffles in triple serpentine flow field
}

\author{
A'rasy Fahruddin $^{1,2, *}$, Djatmiko Ichsani ${ }^{1}$, and Fadlilatul Taufany ${ }^{3}$ \\ ${ }^{1}$ Institut Teknologi Sepuluh Nopember, Mechanical Engineering Department, Faculty of Industrial Technology, Surabaya, \\ Indonesia \\ ${ }^{2}$ Universitas Muhammadiyah Sidoarjo, Mechanical Engineering Department, Faculty of Engineering, Sidoarjo, Indonesia \\ ${ }^{3}$ Institut Teknologi Sepuluh Nopember, Chemical Engineering Department, Faculty of Industrial Technology, Surabaya, Indonesia
}

\begin{abstract}
Baffles in the Polymer Electrolyte Membrane (PEM) fuel cell flow field increase the reactant pressure to gas diffusion layer, enhance reactant mass transfer to the catalyst layer and water discharge under the rib, which in turn improve cell performance. In this study, we perform numerical simulations to investigate triangular baffles configuration in triple serpentine flow fields and compare it with flow field without baffles on cell performance. A 9-layer PEM fuel cell model with $14 \mathrm{~cm} 2$ active area is used. Baffles are arranged in line with single row and two rows transversely to the flow direction. Different flowrate is applied for optimization. In addition, the use of reducers in exhaust is also studied. The results show that flow field with baffles configuration can improve power density by $8 \%$, while current density increase $6 \%$ when compared to non-baffles flow field.
\end{abstract}

\section{Introduction}

Fuel cell is a technology that convert fuel into electrical energy directly. Compared to combustion engines, fuel cells have the advantage of environmentally friendly and more efficient fuel [1-3].

PEM (Polymer Electrolyte Membrane) fuel cell is one type of fuel cell that works at relatively low temperatures making it easy to apply for transportation and other portable equipment $[4,5]$. In addition to its advantages, fuel cell also has a disadvantage that investment costs are still relatively expensive, especially on the price of the catalyst and membrane. The way to reduce the area of the catalyst and the area of the membrane is by increasing the power density. Power density can be improved with many strategies, such as modification of flow field.

Some researchers have conducted a study on flowfield design for fuel cells [6-9]. Limjeerajarus and Charoen [10] has researched some of the flow field designs, and it has been found that the design of the flow field greatly influences the transport behavior and cell performance of the PEM fuel cell. The single serpentine flow field provides the best performance while the parallel flow field is the worst [10,11]. However, multichannel design would be better to reduce pressure drop [10]. Chang and $\mathrm{Wu}$ [5] has researched about the design and depth of the channel in the PEM fuel cell, and found that the triple serpentine design yielded better performance than the parallel serpentine flow field. Sufficient channel depth is required for transport of reactants and water removal, but the deep channel will reduce the convective mass transport thus decreasing the performance of the cell [5]. Some researchers have studied the use of baffles or blockages in the flow field to improve convective mass transport $[12,13]$. Heidary et al. $[14,15]$ has examined in-line and staggered blockages in parallel flow fields numerically and experimentally. The results show that the use of inline blockages can increase the net power up to $3.8 \%$ compared with no blockages. While the use of staggered blockage can increase power to $11 \%$ [14]. Ghanbarian and Kermani [16] has been researching some form of blockages called identation to improve PEM fuel cell performance. The results show that identation enriches the oxygen content in the catalyst layer so increase the generated electrical current, and the identation of the trapezoidal shape shows the best increase in power density compared to the square and circular forms. Wang et al. [17] has examined the use of baffles in the triple serpentine flow field, but the baffles are used fully close several channels, so that the pressure drop increases significantly.

The study of baffles in the triple serpentine flow field with other designs to reduce the pressure drop seems to be necessary. The purpose of this study is to investigate the use of inline triangular baffles in a triple serpentine flow field to improve PEM fuel cell performance.

\section{Method}

This research was conducted by numerical simulation using Ansys Fluent software. The model used is a single stack PEM fuel cell consisting of 9 layers, there are: a

\footnotetext{
* Corresponding author: arasy.fahruddin@umsida.ac.id
} 
pair of current collectors, a pair of reactant fluids, a pair of diffusion layer gases, a pair of catalyst layers, and a membrane [18]. The active membrane area used is 14 $\mathrm{cm}^{2}$. The width and depth of the channel is $1.5 \mathrm{~mm} \times 1$ $\mathrm{mm}$, while the height of the triangular baffle is $0.5 \mathrm{~mm}$.

Triple serpentine flow field type is used with the addition of triangular baffles arranged in line. To know the effect of adding triangle baffle then investigated flow field without baffle, flow field with baffle single row, and flow field with baffle double row. To keep the pressure on the exhaust side is placed a reducer. Flow field design more clearly can be seen in figure 1 .

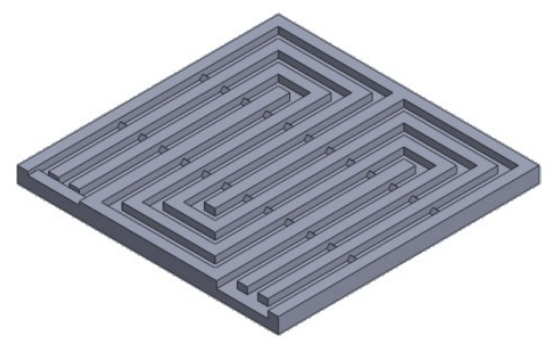

Fig. 1. The design of the triple serpentine flow field with the addition of a two-row baffle.

The model is assumed as a single phase laminer flow with a working temperature of $333 \mathrm{~K}$ and 1 atm operating pressure. The hydrogen and oxygen mass flowrate as the reactant gas is varied to determine the effect of using baffles with different mass flowrate. In more detail the model parameters used are shown in table 1 and table 2.

Table 1. Variations of reactant mass flowrate.

\begin{tabular}{|l|l|l|}
\hline Property & Value & Unit \\
\hline Q1 & & \\
\hline Hidrogen mass flow rate & $6 \times 10^{-7}$ & $\mathrm{~kg} / \mathrm{s}$ \\
\hline Oksigen mass flow rate & $1 \times 10^{-5}$ & $\mathrm{~kg} / \mathrm{s}$ \\
\hline Q2 & & \\
\hline Hidrogen mass flow rate & $1 \times 10^{-6}$ & $\mathrm{~kg} / \mathrm{s}$ \\
\hline Oksigen mass flow rate & $1.5 \times 10^{-5}$ & $\mathrm{~kg} / \mathrm{s}$ \\
\hline
\end{tabular}

Table 2. Model parameters in simulation.

\begin{tabular}{|l|l|l|l|}
\hline Property & \multicolumn{1}{|c|}{ Value } & \multicolumn{1}{|c|}{ Unit } & Ref \\
\hline Gas diffusion layer & & & \\
\hline Density & 321.5 & $\mathrm{Kg} / \mathrm{m}^{3}$ & {$[11]$} \\
\hline Electric conductivity & 280 & $1 / \mathrm{ohm} \cdot \mathrm{m}$ & {$[11]$} \\
\hline Porosity & 0.6 & & {$[14]$} \\
\hline Catalyst layer & & & \\
\hline Porosity & 0.4 & & {$[14]$} \\
\hline Surface to volume ratio & $1.127 \mathrm{x} 10^{7}$ & $\mathrm{M}^{2} \mathrm{Pt} / \mathrm{m}^{3}$ & {$[14]$} \\
\hline Membrane & & & \\
\hline Thermal conductivity & 0.16 & $\mathrm{~W} / \mathrm{mK}$ & {$[11]$} \\
\hline Dry membrane density & 1980 & $\mathrm{Kg} / \mathrm{m}^{3}$ & {$[11]$} \\
\hline Reaction parameters & & & \\
\hline Open circuit voltage & 1.05 & $\mathrm{~V}$ & {$[14]$} \\
\hline $\begin{array}{l}\text { Anode Reference } \\
\text { concentration }\end{array}$ & 0.0008814 & $\mathrm{kmol} / \mathrm{m}^{3}$ & {$[10]$} \\
\hline $\begin{array}{l}\text { Cathode Reference } \\
\text { concentration }\end{array}$ & 0.0008814 & $\mathrm{kmol} / \mathrm{m}^{3}$ & {$[10]$} \\
\hline Anode charge transfer & 1 & & {$[10]$} \\
\hline
\end{tabular}

\begin{tabular}{|l|l|l|l|} 
coefficient & & & \\
\hline $\begin{array}{l}\text { Anode reference current } \\
\text { density }\end{array}$ & 7.17 & $\mathrm{~A} / \mathrm{m}^{2} . \mathrm{Pt}$ & {$[10]$} \\
\hline $\begin{array}{l}\text { Cathode charge transfer } \\
\text { coefficient }\end{array}$ & 1 & & {$[10]$} \\
\hline $\begin{array}{l}\text { Cathode reference current } \\
\text { density }\end{array}$ & $7.17 \times 10^{5}$ & $\mathrm{~A} / \mathrm{m}^{2} . \mathrm{Pt}$ & {$[10]$} \\
\hline
\end{tabular}

\subsection{Governing equation}

In this study the governing equation used includes the following transport equations [18]:

$$
\nabla \cdot(\rho \varphi \overrightarrow{\mathrm{V}})=\nabla \cdot\left(\Gamma_{\varphi} \nabla \varphi\right)+\mathrm{S}_{\varphi}
$$

where $\varphi$ is transport quantity, $\rho$ is mixture density, $V$ is velocity, $\Gamma$ is diffusivity, and $S$ is source term. Driving force electrochemical reactions that occur is a potential in solid phase and phase membrane [18]:

$$
\nabla \cdot\left(\sigma_{\mathrm{s}} \nabla \phi_{\mathrm{s}}\right)=-R_{\mathrm{s}}, \nabla \cdot\left(\sigma_{m} \nabla \phi_{m}\right)=-R_{m}
$$

where $\sigma$ is electrical conductivity, $\varnothing$ is potential, and $R$ is electrical current, while $\mathrm{s}$ and $\mathrm{m}$ are solid and membrane phase. For solid phase $R s=-R a$ on the anode side, $R s=$ $+R c$ on the cathode side. While on the membrane phase, $R m=+R a$ on the anode side and $R m=-R c$ on the cathode side.

$R a$ and $R c$ are derived from the Butler-Volmer equation as follows $[14,18]$ :

$$
\begin{gathered}
R_{a}=\zeta_{a} i_{a}^{r e f}\left(\frac{\left[\mathrm{H}_{2}\right]}{\left[\mathrm{H}_{2}\right]_{\text {ref }}}\right)^{\gamma_{a}}\left(e^{\alpha_{a} F^{\eta_{a}} / R T}-e^{-\alpha_{c} F^{\eta_{a}} / R T}\right) \\
R_{c}=\zeta_{c} \mathrm{i}_{c}^{r e f}\left(\frac{\left[\mathrm{O}_{2}\right]}{\left[\mathrm{O}_{2}\right]_{\text {ref }}}\right)^{\gamma_{c}}\left(-e^{\alpha_{a} F^{\eta_{c}} / R T}+e^{-\alpha_{c} F^{\eta_{c}} / R T}\right) \\
\eta_{a}=\left(\phi_{\mathrm{s}}-\phi_{m}\right) \\
\eta_{c}=\left(\phi_{\mathrm{s}}-\phi_{m}-\mathrm{V}_{\mathrm{oc}}\right)
\end{gathered}
$$

where $i^{r e f}$ is the volumetric reference exchange current densities, $\alpha_{a}$ and $\alpha_{c}$ are anode and cathode transfer coefficients, $\gamma_{a}$ and $\gamma_{c}$ are anode and cathode concentration exponents, $\eta_{a}$ and $\eta_{c}$ are the anode and cathode overpotentials, while the $V_{o c}$ is open circuit voltage.

\subsection{Validation}

In this study the results of numerical simulations are compared with the results of experiments conducted by Chang [5]. As shown in figure 2, the simulation results on the triple serpentine channel without baffles approached the experimental results performed by Chang on the triple serpentine channel. Differences occur due to the different width and depth of channels between simulations and experiments. 


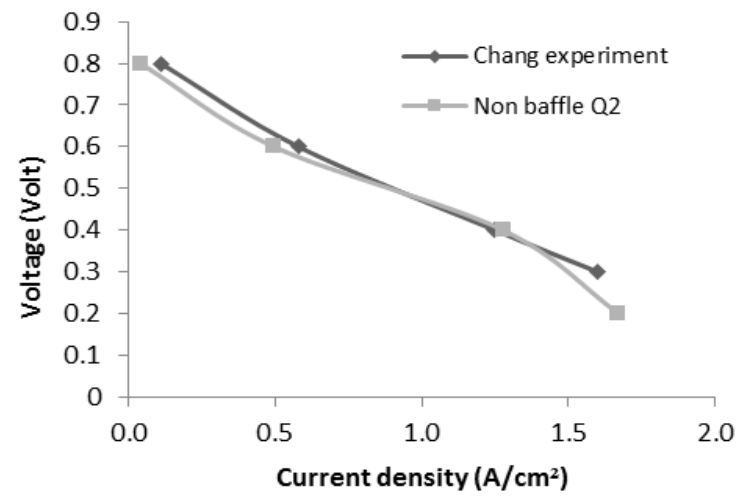

Fig. 2. Validation of simulation results with experiment.

\section{Results and Discussion}

In figure 3 , it can be seen that the distribution of hydrogen molar fractions for non-baffled channels, channels with single-row baffles, and channels with tworow baffles is almost uniform. This suggests that the use of baffles in the hydrogen channel can not have a significant effect on hydrogen mass transfer on the anode side, in accordance with Hadi's statement [14]. However, the difference is still there, on the use of baffles area under the rib looks brighter that shows the concentration of hydrogen more evenly.

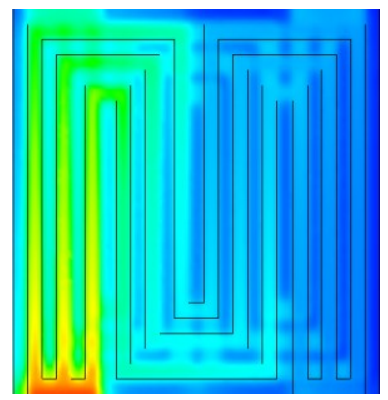

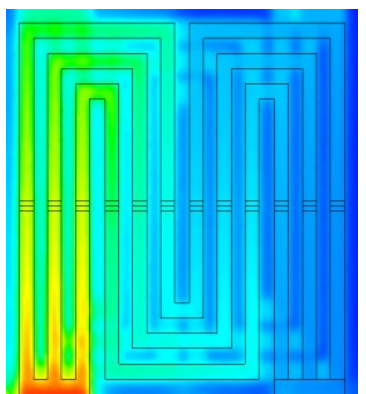

$\mathrm{b}$

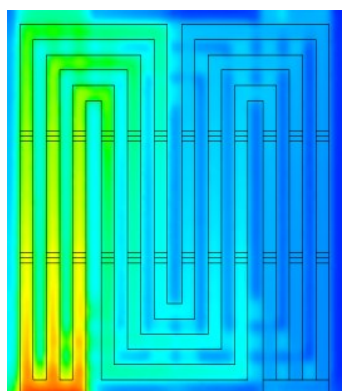

c

Fig. 3. Distribution of hydrogen molar fraction: a. Non baffles, b. single row baffles, c. double row baffles

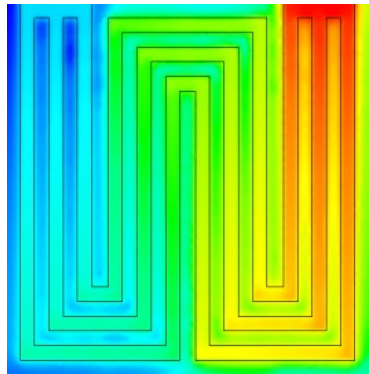

a

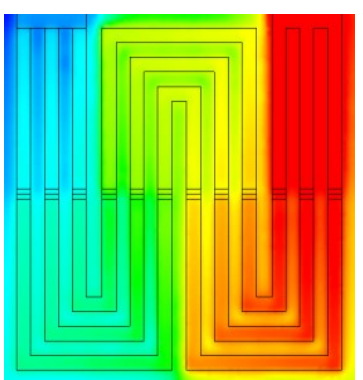

$\mathrm{b}$

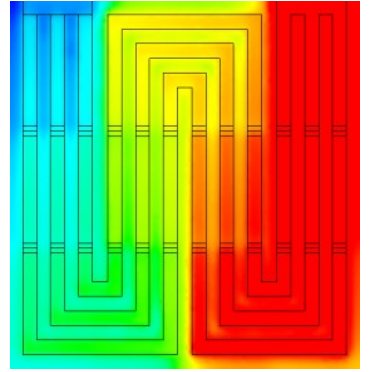

c

Fig. 4. Distribution of oxygen pressure in GDL: a. Non baffles, b. single row baffles, c. double row baffles.

In figure 4 it can be seen that the use of baffles will increase the oxygen pressure in the GDL layer. The use of two-row baffles shows the greatest oxygen pressure. Increased oxygen pressure indicates a greater oxygen supply on the cathode side, thus favoring a reaction to a larger electric current operation. However, large oxygen supply does not necessarily increase the amount of oxygen that reacts. While the reducer on the exhaust side is used to keep the output pressure not too low. In figure 4 can be seen, the output pressure in the flow field with the baffle approaches the output pressure in the flow field without baffle.

Figure 5 shows a polarization graph that compares between a flow field without a baffle, a flow field with a single row baffle and two rows. From Figure 5 it can be seen that the use of baffles can increase the current density especially in low voltage areas. In low-voltage areas the fuel cell performance depends on the supply of adequate reactants. The use of baffles will increase the reactant pressure toward the catalyst thus increasing the supply of the reactants and reducing the concentration losses. The increase of current density in baffle usage can reach up to $6 \%$ when compared with no baffles. Flow field with two-row baffles can achieve a larger current density than in a flow field with a single row baffle, but the difference is not significant. This is due to limited hydrogen transfer. 


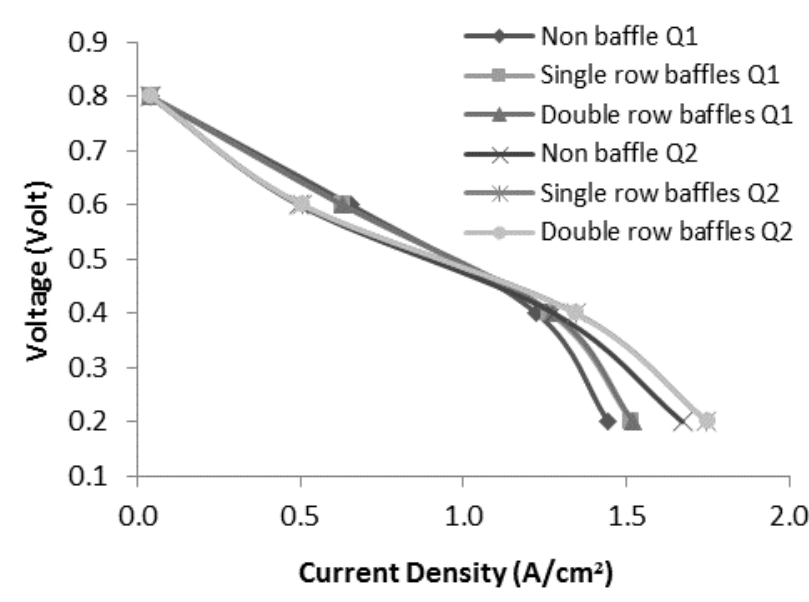

Fig. 5. Polarization graph with variation of flow field and mass flowrate variation.

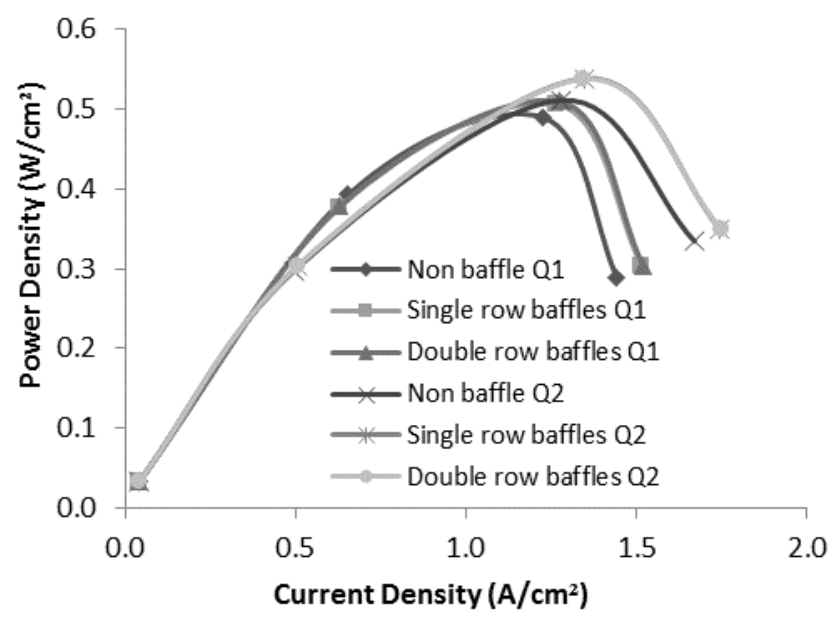

Fig. 6. Power density graph with variation of flow field and variation of mass flowrate.

In larger mass flowrate, current density is increasing. And the use of baffles still produce a larger current density when compared with no baffles. However, larger mass flowrate will decrease cell efficiency in low current region. Because high reactant flowrate will reduce the reactant touch time to GDL, thus decreasing the potential difference.

In figure 6 we can see that the use of baffles can increase the power density cell, either at low reactant mass flowrate or in larger reactant mass flowrate. Increased power density in flow field with baffle can reach up to $8 \%$ when compared with flow field without baffle. In figure 6 it can also be seen that the power density in the flow field with baffles with low mass flowrate can match the power density flow field without baffle with larger reactant mass flowrate.

\section{Conclusion}

From this research, it can be concluded that the use of baffle can increase current density up to $6 \%$ when compared without baffle, and power density can increase up to $8 \%$. This is because the use of baffles will increase the reactant pressure toward the catalyst so that it will increase the supply of reactants in the catalyst. The amount of reactant supply will reduce concentration losses when the cell is working on a larger electric current.

\section{References}

1. Haile, S. M. Fuel cell materials and components. Acta Mater. Journals 51, 5981-6000 (2003).

2. Wang, Y., Mishler, J. \& Adroher, X. C. A review of polymer electrolyte membrane fuel cells: Technology, applications, and needs on fundamental research. Appl. Energy (2011).

3. Siegel, C. Review of computational heat and mass transfer modeling in polymer-electrolyte-membrane (PEM) fuel cells. Energy 33, 1331-1352 (2008).

4. Mohamed, W. A. N. W. \& Kamil, M. H. M. Hydrogen preheating through waste heat recovery of an open-cathode PEM fuel cell leading to power output improvement. Energy Convers. Manag. 124, 543-555 (2016).

5. Chang, D. H. \& Wu, S. Y. The effects of channel depth on the performance of miniature proton exchange membrane fuel cells with serpentine-type flow fields. Int. J. Hydrogen Energy 40, 1165911667 (2015).

6. Li, X. \& Sabir, I. Review of bipolar plates in PEM fuel cells: Flow-field designs. Int. J. Hydrogen Energy 30, 359-371 (2005).

7. Manso, A. P., Marzo, F. F., Barranco, J., Garikano, X. \& Mujika, M. G. Influence of geometric parameters of the flow fields on the performance of a PEM fuel cell. A review. Int. J. Hydrogen Energy 37, 15256-15287 (2012).

8. Liu, H., Li, P. \& Wang, K. Optimization of PEM fuel cell flow channel dimensions d Mathematic modeling analysis and experimental verification. Int. J. Hydrogen Energy 38, 9835-9846 (2013).

9. Hossain, M. S., Shabani, B. \& Cheung, C. P. Enhanced gas flow uniformity across parallel channel cathode flow field of Proton Exchange Membrane fuel cells. Int. J. Hydrogen Energy 42, 5272-5283 (2016).

10. Limjeerajarus, N. \& Charoen-Amornkitt, P. Effect of different flow field designs and number of channels on performance of a small PEFC. Int. J. Hydrogen Energy 40, 7144-7158 (2015).

11. Iranzo, A., Muñoz, M., Rosa, F. \& Pino, J. Numerical model for the performance prediction of a PEM fuel cell. Model results and experimental validation. Int. J. Hydrogen Energy 35, 1153311550 (2010).

12. Handoyo, E. A., Ichsani, D., Prabowo \& Sutardi. Experimental Studies on a Solar Air Heater Having V-Corrugated Absorber Plate with Obstacles Bent Vertically. Appl. Mech. Mater. 493, 86-92 (2014).

13. Hakam, M., Ichsani, D. \& Suroso, C. Numerical investigation of heat transfer and fluid flow characteristic of V-corrugated plate solar air collector with prismatic fin as an extended surface. AIP Conference Proceedings 1778, (2016). 
14. Heidary, H., Kermani, M. J., Prasad, A. K., Advani, S. G. \& Dabir, B. Numerical modelling of in-line and staggered blockages in parallel flowfield channels of PEM fuel cells. Int. J. Hydrogen Energy 42, 2265-2277 (2017).

15. Heidary, H., Kermani, M. J., Advani, S. G. \& Prasad, A. K. Experimental investigation of in-line and staggered blockages in parallel flowfield channels of PEM fuel cells. Int. J. Hydrogen Energy 41, 6885-6893 (2016).

16. Ghanbarian, A. \& Kermani, M. J. Enhancement of PEM fuel cell performance by flow channel indentation. Energy Convers. Manag. 110, 356-366 (2016).

17. Wang, X. D., Duan, Y. Y. \& Yan, W. M. Novel serpentine-baffle flow field design for proton exchange membrane fuel cells. J. Power Sources 173, 210-221 (2007).

18. Heidary, H., Kermani, M. J. \& Dabir, B. Influences of bipolar plate channel blockages on PEM fuel cell performances. Energy Convers. Manag. 124, 51-60 (2016). 